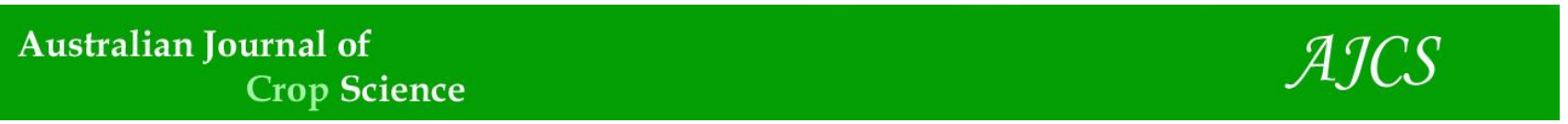

AJCS 14(11):1736-1741 (2020)

ISSN:1835-2707

doi: 10.21475/ajcs.20.14.11.p2410

\title{
Production and photosynthetic pigments of bell peppers all big (Capsicum annuum L.) subjected to fertilization with biochar and nitrogen
}

\section{André Alisson Rodrigues da Silva*, Lucia Helena Garófalo Chaves Antônio Ramos Cavalcante, Washington Benevenuto de Lima, Luan Dantas de Oliveira, Benedito Ferreira Bonifácio, Robson Fabio Alves de Souza, Ronaldo do Nascimento}

\author{
Federal University of Campina Grande, Academic Unit of Agricultural Engineering, Campina Grande, 58.109-970, \\ Paraíba, Brazil
}

*Corresponding author: andrealisson_cgpb@hotmail.com

\begin{abstract}
The Northeastern semi-arid region provides favorable conditions for bell pepper cultivation, but most often the low availability of soil nutrients to plants constitutes a limiting factor to production. In this context, the present study aimed to evaluate the production and photosynthetic pigments of bell pepper subjected to increasing levels of fertilization with biochar and nitrogen. The experiment was conducted in pots (Citropote) under greenhouse conditions. Treatments were arranged in a completely randomized design, in $4 \times 4$ factorial scheme, relative to four doses of biochar $\left(0 ; 7 ; 14\right.$ and $21 \mathrm{~m}^{3}$ ha $\left.\mathrm{h}^{-1}\right)$ and four doses of nitrogen $\left(0 ; 40 ; 80\right.$ and $\left.120 \mathrm{~kg} \mathrm{ha}^{-1}\right)$, with three replicates. Fertilization with $70 \mathrm{~kg} \mathrm{ha}^{-1}$ of nitrogen and $14 \mathrm{~m}^{3} \mathrm{ha}^{-1}$ of biochar promotes highest yield of bell pepper in terms of number of fruits and fruit fresh weight per plant. The highest contents of photosynthetic pigments were obtained in plants fertilized with $70 \mathrm{~kg} \mathrm{ha}^{-1}$ of nitrogen associated with $10 \mathrm{~m}^{3} \mathrm{ha}^{-1}$ of biochar. Biochar doses above $15.54 \mathrm{~m}^{3}$ $\mathrm{ha}^{-1}$ negatively affect the longitudinal diameter of bell pepper fruits. The recommendation of $120 \mathrm{~kg} \mathrm{ha}^{-1}$ of nitrogen and $20 \mathrm{~m}^{3}$ ha ${ }^{-1}$ of biochar reduces bell pepper production and photosynthetic pigments.
\end{abstract}

Keywords: protected cultivation, fertilization, Capsicum annuum L.

Abbreviations: DAS_days after sowing; NF_number of fruits; FFW_fruit fresh weight; FDW_fruit dry weight; FLD_fruit longitudinal diameter; FTD_fruit transverse diameter; Chla_chlorophyll $a$; Chlb_chlorophyll $b$; Total Chl_total chlorophyll; Car_carotenoids.

\section{Introduction}

Bell pepper (Capsicum annuum L.) is considered one of the most cultivated vegetables in Brazil (Souza et al., 2018). According to FAO (2017), the country has an estimated planting area of 19 thousand hectares and production above 420 thousand tons per year. The Northeastern semi-arid region provides adequate edaphoclimatic conditions for production, and the states of Pernambuco, Paraíba, Ceará and Bahia are the main producers in the Northeast region (Nascimento, 2014).

The use of organic matter in soil promotes direct and indirect effects on some chemical and physical phenomena. It is related to the large specific surface area and high quantity of surface charges and, indirectly, the organic matter interferes with the physical activity of the soil, acting in the formation of aggregates and, therefore, in pore-size distribution (Chaves et al., 2018).

Lately the use of biochar as source of organic matter has proven to be promising, due to the wide range of benefits for agriculture (Kavitha et al., 2018). Biochar is a carbon-rich solid material obtained through biomass pyrolysis (Godlewska et al., 2017). According to Tammeorg et al. (2017), biochar improves nutrient and water retention in the soil, consequently improving plant growth and development. In addition, studies conducted with biochar have found that its use increases the total nitrogen in soil and reduces nitrogen losses through leaching due to $\mathrm{NH}_{4}{ }^{+}$adsorption onto the biochar surface (Chen et al., 2010; López-Cano et al., 2016).

According to Aragão et al. (2013), nitrogen is the most important nutrient for bell pepper, being directly related to plant and fruit growth. However, its deficiency occur in virtually all soils. The high mobility of $\mathrm{NO}_{3}{ }^{-}$in soil justifies the concern about nitrogen fertilization management in agricultural soils because nitrate leaching is a physical phenomenon, favored by the low binding energy to clay minerals, so it can be lost to the subsurface layers of the soil profile (Vanotti and Bundy, 1994).

Chlorophylls are pigments which reflect the green color and are directly associated with the potential for photosynthetic activity (Silva et al., 2014). Chlorophyll $a$ is the pigment used to perform the photochemical phase, i.e., the first phase of the photosynthetic process, while the other pigments help in light absorption and radiant energy transfer to the reaction centers, hence being called accessory pigments (Streit et al., 2005).

In order to identify adequate doses of biochar and nitrogen for agricultural exploitation in semi-arid regions, the present study aimed to evaluate the production and photosynthetic pigments of bell pepper subjected to fertilization with biochar and nitrogen. 


\section{Results and discussion}

\section{Effect of biochar and nitrogen doses on sweet pepper production}

Biochar doses significantly influenced all variables studied, except fruit transverse diameter (FTD), while $\mathrm{N}$ doses significantly affected $(p<0.01)$ only the number of fruits (NF) and fruit dry weight (FDW). However, the interaction between these factors had significant effect $(p<0.01)$ on the number of fruits (NF) and fruit fresh weight (FFW) (Table 1). According to the regression equation (Figure $1 A$ ), bell pepper plants in the control treatment, i.e., under no application of either biochar or $\mathrm{N}$, produced the lowest number of fruits (3.98 fruits). However, the application of 14 $\mathrm{m}^{3} \mathrm{ha}^{-1}$ of biochar combined with $70 \mathrm{~kg} \mathrm{ha}^{-1}$ of $\mathrm{N}$ led to the highest number of fruits (10.08 fruits), corresponding to an increment of $153.27 \%$ (6.10 fruits) compared to nonfertilized plants (control). Such response highlights the importance of using biochar as source of organic matter because, when applied in adequate doses, along with $\mathrm{N}$ fertilization, it increases crop production. According to Liu et al. (2014), biochar acts by improving soil chemical and physical properties, promoting plant growth and increasing yield.

The beneficial effect of $\mathrm{N}$ up to the dose of $70 \mathrm{~kg} \mathrm{ha}^{-1}$ may be related to the efficiency of this element in increasing bell pepper production, hence improving the supply of amino acids and other organic substances, promoted by the higher photosynthetic efficiency (Campos et al., 2008). Similar results were obtained by Ayodele et al. (2015), evaluating the effect of $\mathrm{N}$ fertilization on pepper (Capsicum spp.), and the highest number of fruits was obtained with $\mathrm{N}$ application of $75 \mathrm{~kg} \mathrm{ha}^{-1}$.

The highest fruit fresh weight (35.3 g) was obtained with application of $7 \mathrm{~m}^{3} \mathrm{ha}^{-1}$ of biochar and $80 \mathrm{~kg} \mathrm{ha}^{-1}$ of $\mathrm{N}$, representing an increase of $51.5 \%(12.0 \mathrm{~g})$ compared to plants in the control treatment. On the other hand, the lowest fruit fresh weight $(16.24 \mathrm{~g})$ was obtained with application of $21 \mathrm{~m}^{3} \mathrm{ha}^{-1}$ of biochar and $0 \mathrm{~kg} \mathrm{ha}^{-1}$ of $\mathrm{N}$ (Figure 1B). The beneficial effect of biochar and $\mathrm{N}$ application on fruit fresh weight is possibly due to the better efficiency in $\mathrm{N}$ use. According to Coelho et al. (2018), the use of biochar combined with fertilizers can be an important strategy in large areas intended for agricultural practices, because the addition of these organo-mineral fertilizers can reduce $\mathrm{N}$ losses and improve $\mathrm{N}$ use efficiency in plants. In addition, the application of organic residues to agricultural soils has been used as a practical alternative to reduce environmental impacts and improve soil quality (Zhao et al., 2016).

The biochar doses stimulated FDW and its data fitted to a quadratic model (Figure 2A), with maximum estimated value of $23.5 \mathrm{~g}$ in plants subjected to $12.8 \mathrm{~m}^{3} \mathrm{ha}^{-1}$ of biochar, decreasing from this dose. This probably occurred due to the improvement in soil quality because, according to Silva et al. (2017), soil chemical, physical and biological properties are improved with biochar application, causing higher growth and yield of crops in this soil. Additionally, biochar is a source of nutrients that can increase soil $\mathrm{pH}$, favoring the reduction in soil acidity and aluminum toxicity (Gwenzi et al., 2016). The minimum FDW value was $13.19 \mathrm{~g}$, observed in bell pepper plants which were not fertilized with biochar.

Fruit dry weight (FDW) was also positively affected by $\mathrm{N}$ application (Figure 2B). The linear model fitted indicates that the highest FDW (21.76 g) was obtained with $\mathrm{N}$ dose of 120 $\mathrm{kg} \mathrm{ha}^{-1}$, while the lowest FDW (16.86 g) was observed in plants grown in the absence of $\mathrm{N}$ fertilization $\left(0 \mathrm{~kg} \mathrm{ha}^{-1}\right)$, i.e., a reduction of $22.52 \%(4.9 \mathrm{~g})$ between the highest $(120 \mathrm{~kg}$ $\left.\mathrm{ha}^{-1}\right)$ and lowest $\left(0 \mathrm{~kg} \mathrm{ha}^{-1}\right)$ doses of $\mathrm{N}$. Similar results were obtained by Ferreira et al. (2003), studying the effect of $N$ doses on the tomato crop, since these authors observed increment in dry weight with increasing $\mathrm{N}$ doses.

In relation to fruit longitudinal diameter (FLD), the regression equation (Figure 3 ) revealed a quadratic effect of biochar doses, with maximum estimated value of $60.3 \mathrm{~mm}$ in plants subjected to $15.54 \mathrm{~m}^{3} \mathrm{ha}^{-1}$ of biochar, decreasing from this dose. The minimum value $(53.12 \mathrm{~mm})$ was found in bell pepper plants which were not fertilized with biochar, i.e., there was a reduction of $13.56 \%(7.18 \mathrm{~mm})$. Increase in FLD up to the dose of $15.54 \mathrm{~m}^{3} \mathrm{ha}^{-1}$ can be justified by the fact that biochar applied at adequate doses increases nutrient availability and water absorption by plants (Hammer et al., 2014).

\section{Effect of biochar and nitrogen doses on sweet pepper chlorophyll}

Based on the $\mathrm{F}$ test summary (Table 2), the photosynthetic pigments of bell pepper, evaluated based on chlorophyll $a$ (Chla), chlorophyll $b$ (Chlb), total chlorophyll (Total Chl) and carotenoids (Car), were significantly affected $(p<0.01)$ by the interaction between biochar doses and $\mathrm{N}$ doses. Biochar doses affected all variables analyzed, except total chlorophyll. In regard to $\mathrm{N}$ doses, there was significant effect ( $p<0.01$ ) on chlorophyll $a$, total chlorophyll and carotenoids.

The interaction between biochar doses and $\mathrm{N}$ doses significantly influenced the chlorophyll $a$ content. The regression equation (Figure $4 \mathrm{~A}$ ) shows that plants fertilized with $70 \mathrm{~kg} \mathrm{ha}^{-1}$ of $\mathrm{N}$ and $10 \mathrm{~m}^{3} \mathrm{ha}^{-1}$ of biochar had the highest chlorophyll $a$ content (1596 $\mathrm{mg} \mathrm{g}^{-1} \mathrm{FM}$ ). On the other hand, bell pepper plants in the control treatment had a chlorophyll $a$ content of $1065.67 \mathrm{mg} \mathrm{g}^{-1} \mathrm{FM}$, corresponding to a reduction of $33.23 \%$ ( $\left.530.33 \mathrm{mg} \mathrm{g}^{-1} \mathrm{FM}\right)$ compared to plants with the highest chlorophyll $a$ content. The lowest Chla content (1028.51 $\mathrm{mg} \mathrm{g}^{-1} \mathrm{FM}$ ) was obtained in plants fertilized only with $21 \mathrm{~m}^{3} \mathrm{ha}^{-1}$ of biochar.

For chlorophyll $b$ in bell pepper plants (Figure 4B), the effect was similar to the one on chlorophyll $a$, i.e., fertilization with $70 \mathrm{~kg} \mathrm{ha}^{-1}$ of $\mathrm{N}$ and $10 \mathrm{~m}^{3} \mathrm{ha}^{-1}$ of biochar led to the highest content of chlorophyll $b$ (592.18 $\left.\mathrm{mg} \mathrm{g}^{-1} \mathrm{FM}\right)$. Plants in the control treatment, i.e., under no fertilization, obtained chlorophyll $b$ content of $373.56 \mathrm{mg} \mathrm{g}^{-1} \mathrm{FM}$, corresponding to a reduction of $36.92 \%$ ( $218.62 \mathrm{mg} \mathrm{g}^{-1} \mathrm{FM}$ ) compared to those with highest chlorophyll $b$ content.

As observed for chlorophyll $a$ and chlorophyll $b$, plants fertilized with $70 \mathrm{~kg} \mathrm{ha}^{-1}$ of $\mathrm{N}$ and $10 \mathrm{~m}^{3} \mathrm{ha}^{-1}$ of biochar obtained the highest contents of total chlorophyll (Figure 4C) and carotenoids (Figure 4D). Based on the regression equation, the highest values were $2188.18 \mathrm{mg} \mathrm{g}^{-1} \mathrm{FM}$ for total chlorophyll and $423.13 \mathrm{mg} \mathrm{g}^{-1} \mathrm{FM}$ for carotenoids. However, bell pepper plants which were not fertilized with $\mathrm{N}$ $\left(0 \mathrm{~kg} \mathrm{ha}^{-1}\right)$ and biochar $\left(0 \mathrm{~m}^{3} \mathrm{ha}^{-1}\right)$ reached values of 1408.85 $\mathrm{mg} \mathrm{g}^{-1} \mathrm{FM}$ for total chlorophyll and $273.42 \mathrm{mg} \mathrm{g}^{-1} \mathrm{FM}$ for carotenoids, which corresponded to reductions of 35.62 and $34.67 \%$ in Total Chl and Car, respectively, compared to those which had the highest values. 
Table 1. Summary of $F$ test for number of fruits (NF), fruit fresh weight (FFW), fruit dry weight (FDW), fruit longitudinal diameter (FLD) and fruit transverse diameter (FTD) of bell pepper subjected to increasing levels of fertilization with biochar and nitrogen.

\begin{tabular}{|c|c|c|c|c|c|}
\hline \multirow{2}{*}{ Source of variation } & \multicolumn{5}{|l|}{ F Test } \\
\hline & NF & FFW & FDW & FLD & FTD \\
\hline Linear regression & $* *$ & ns & ns & ns & ns \\
\hline Doses of nitrogen $(\mathrm{N})$ & $* *$ & ns & $* *$ & ns & ns \\
\hline Linear regression & ns & ns & $* *$ & ns & ns \\
\hline Quadratic regression & $* *$ & ns & ns & ns & ns \\
\hline CV (\%) & 19.03 & 13.24 & 23.44 & 11.37 & 11.04 \\
\hline
\end{tabular}

Table 2. Summary of $\mathrm{F}$ test for chlorophyll $a$ (Chla), chlorophyll $b$ (Chlb), total chlorophyll (Total Chl) and carotenoids (Car) of bell pepper plants subjected to increasing levels of fertilization with biochar and nitrogen.

\begin{tabular}{lcccc}
\multicolumn{1}{c}{ Source of variation } & \multicolumn{3}{c}{ F Test } \\
\cline { 2 - 5 } & Chla & Chlb & Total Chl & Car \\
\hline Doses of Biochar (B) & $*$ & $*$ & $\mathrm{~ns}$ & $* *$ \\
Linear regression & $* *$ & $\mathrm{~ns}$ & $\mathrm{~ns}$ & $*$ \\
Quadratic regression & $\mathrm{ns}$ & $*$ & $\mathrm{~ns}$ & $\mathrm{~ns}$ \\
Doses of nitrogen (N) & $* *$ & $\mathrm{~ns}$ & $* *$ & $* *$ \\
Linear regression & $\mathrm{ns}$ & $\mathrm{ns}$ & $\mathrm{ns}$ & $\mathrm{ns}$ \\
Quadratic regression & $* *$ & $\mathrm{~ns}$ & $* *$ & $* *$ \\
Interaction (B x N) & $* *$ & $* *$ & $* *$ & \\
\hline $\mathrm{CV}$ (\%) & 11.87 & 17.25 & 11.54 & 11.80 \\
\hline
\end{tabular}

$\mathrm{ns}, * *, *$ Respectively not significant, significant at $\mathrm{p} \leq 0.01$ and $\mathrm{p} \leq 0.05$

(A)

$\mathrm{NF}=3.984375+0.084896875 \mathrm{x}-0.00059960937 \mathrm{x}^{2}+0.45916071 \mathrm{y}-0.017002551 \mathrm{y}^{2}$

$\mathrm{FFW}=23.325375+0.226596870 \mathrm{x}-0.0013902344 \mathrm{x}^{2}+0.77583929 \mathrm{y}-0.052997449 \mathrm{y}^{2}$
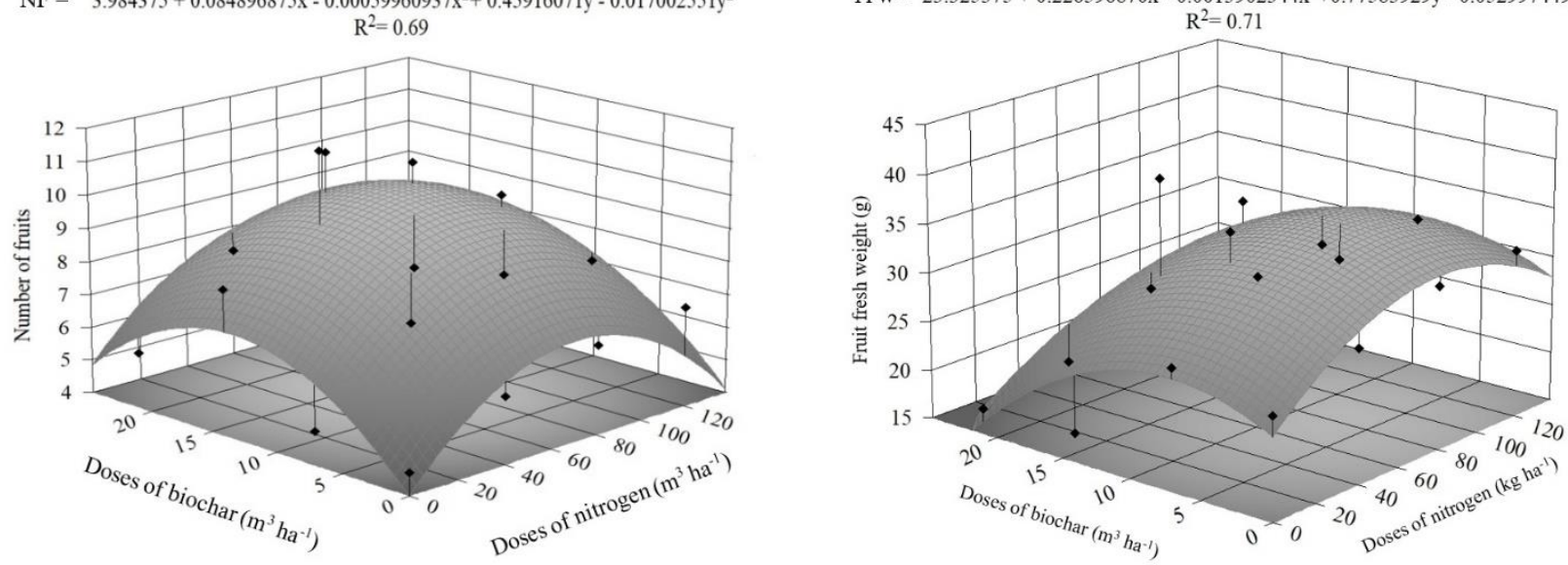

Fig 1. Number of fruits - NF (A) and fruit fresh weight - FFW (B) in bell pepper plants as a function of the interaction between biochar doses and nitrogen doses. $X$ and $Y$ correspond to nitrogen doses and biochar doses, respectively.
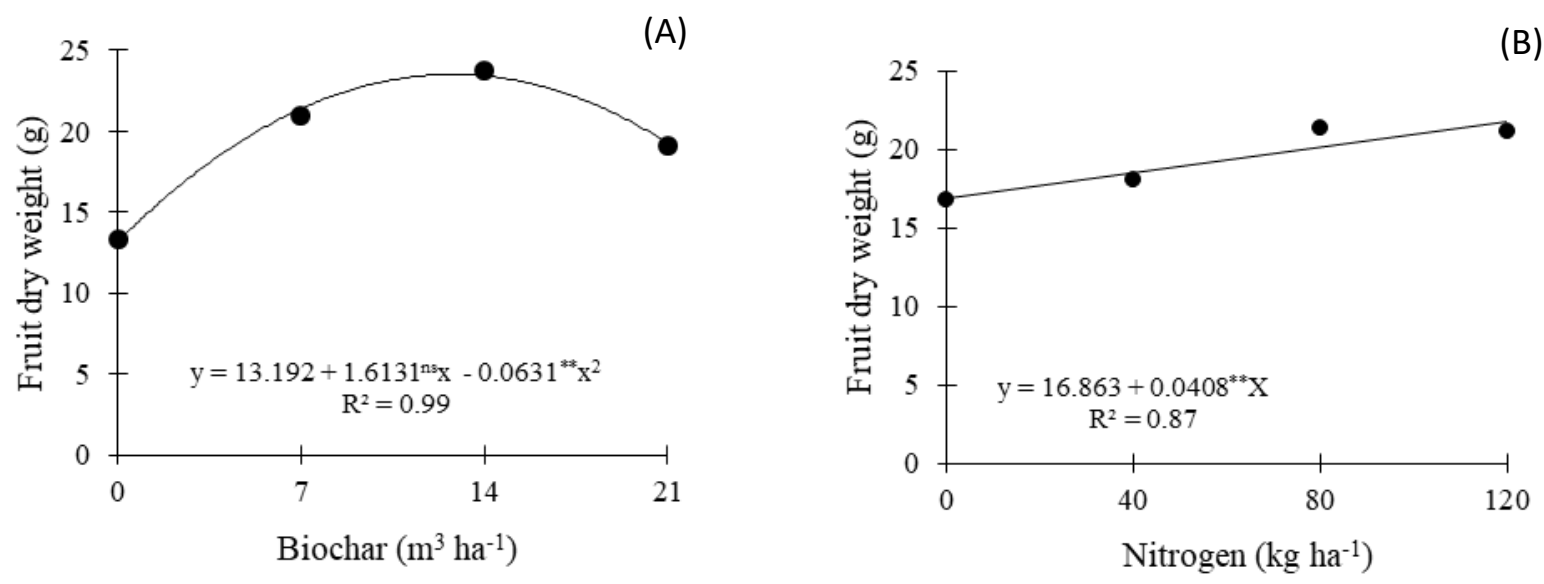

Fig 2. Fruit dry weight - FDW (A) as a function of biochar doses and Fruit dry weight - FDW (B) as a function of nitrogen doses. 


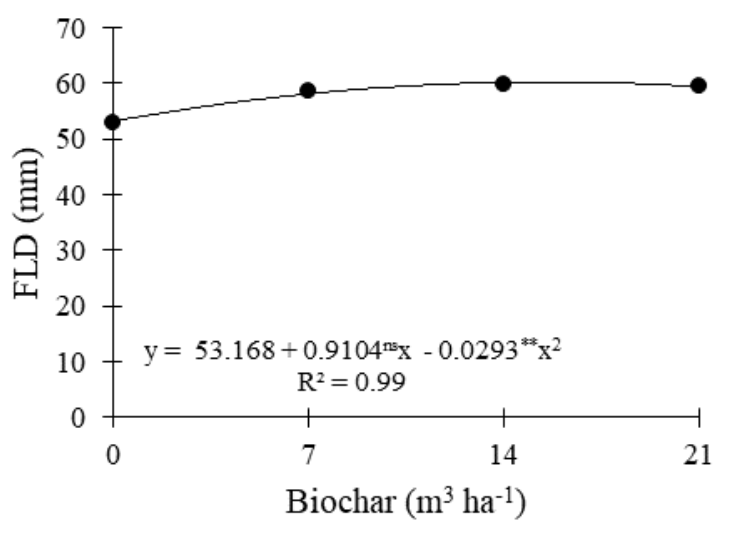

Fig 3. Fruit longitudinal diameter (FLD) as function of biochar doses.
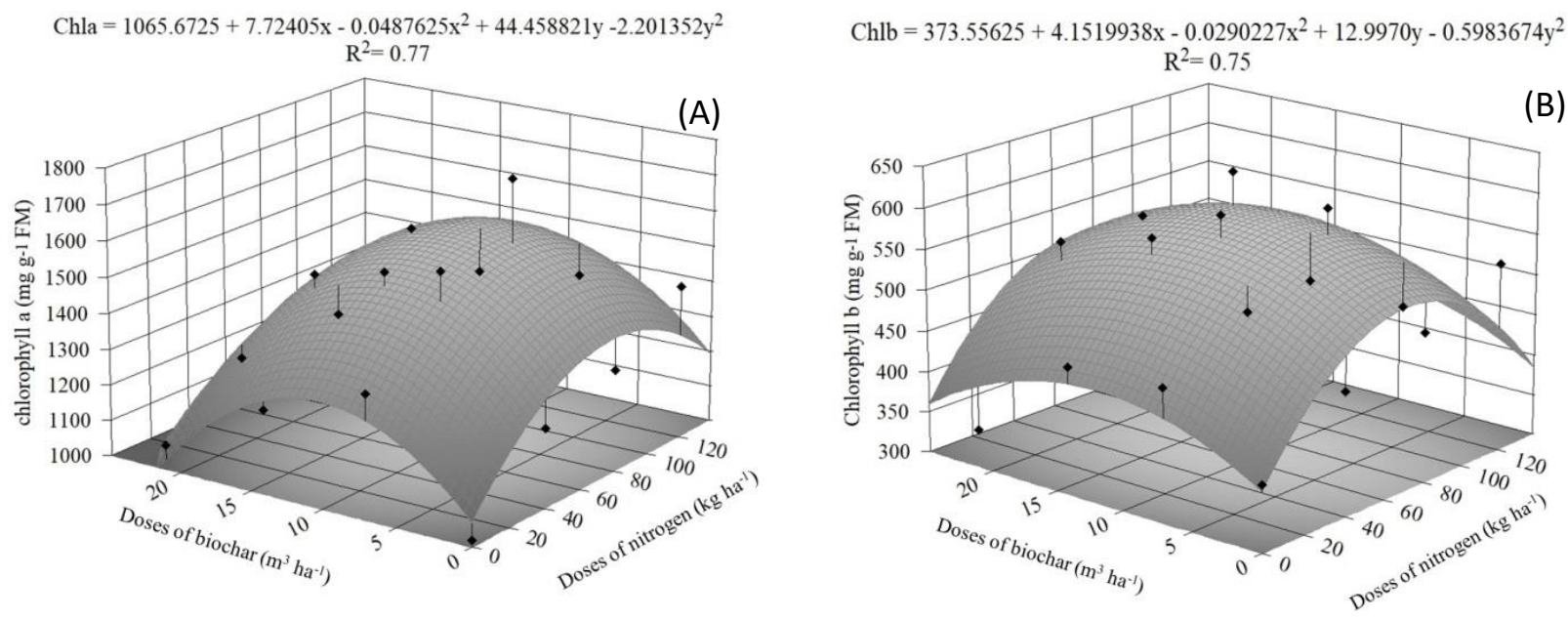

(C) Chl totoal $=1408.8516+13.724866 \mathrm{x}-0.09196289 \mathrm{x}^{2}+51.650554 \mathrm{y}-2.3729974 \mathrm{y}^{2}$

$\mathrm{Car}=276.41613+2.2672469 \mathrm{x}-0.015566797 \mathrm{x}^{2}+10.978661 \mathrm{y}-0.45501276 \mathrm{y}^{2}$

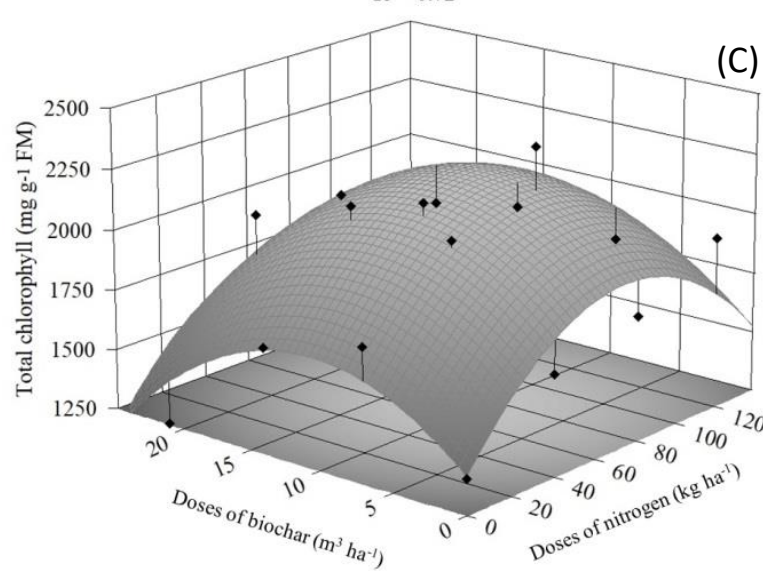

(C)

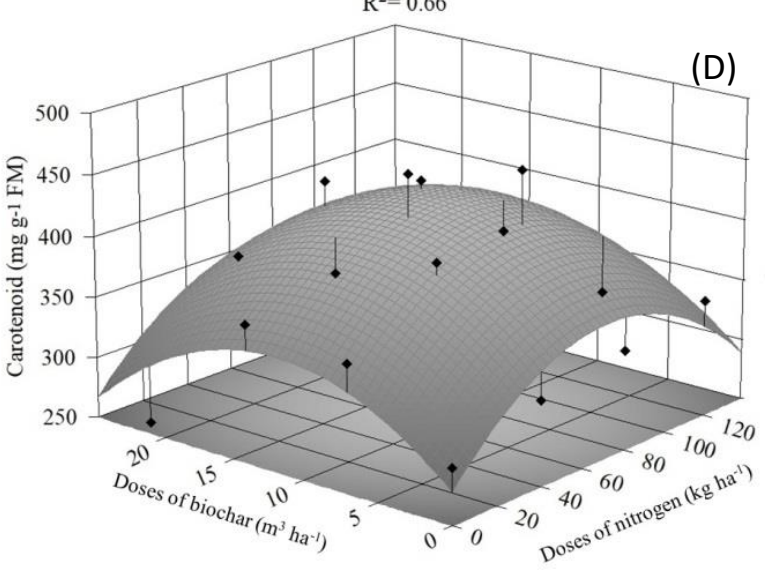

Fig 4. Chlorophyll $a(\mathrm{~A})$, chlorophyll $b$ (B), Total chlorophyll (C) and Carotenoids (D) of bell pepper as a function of the interaction between biochar doses and nitrogen doses. $X$ and $Y$ correspond to nitrogen doses and biochar doses, respectively.

According to Taiz and Zeiger (2017), photosynthetic pigments play an important role in the photosynthetic process, and chlorophylls are responsible for capturing light energy, pointing to chlorophyll $a$ as the main pigment of the light-harvesting complexes for photochemical reactions. Along with chlorophyll $b$, carotenoids constitute the so called accessory pigments (Streit et al., 2005), which play an essential role in photo-protection (Taiz; Zeiger, 2017).

A study conducted by Bhuvaneswari et al. (2014), evaluating the effect of $\mathrm{N}$ fertilization on the chlorophyll content of bell pepper, found that the highest chlorophyll content was obtained in plants fertilized with $50 \mathrm{~kg} \mathrm{ha}^{-1}$ of $\mathrm{N}$ and the lowest content was observed in plants which received no $\mathrm{N}$ fertilization. These authors attributed the beneficial effect of $\mathrm{N}$ to the fact that it is a constituent of the chlorophyll molecule, being the main component of all amino acids in proteins and lipids which act as structural compounds of chloroplast. In addition, the application of biochar along with $\mathrm{N}$ can improve the efficiency of $\mathrm{N}$ use in plants and reduce losses through leaching (Coelho et al., 2018). 


\section{Materials and methods}

\section{Plant materials}

The bell pepper cultivar used in the experiment was All Big, belonging to the Cascadura group; This material has erect growth, small size, firm and thick, sweet-tasting pulp, high productivity and a cycle of around 120 days, and it is tolerant to collar rot (Phytophthora capsici) and common mosaic (ToMV) (Lima et al., 2016).

\section{Experimental site}

The experiment was carried out in the period from August to November 2018, under greenhouse conditions at the Agricultural Engineering Department of the Federal University of Campina Grande, Campina Grande, PB, Brazil (712'52" S; 3554'24" W and mean altitude of $550 \mathrm{~m}$ ), using soil samples collected in the $0-20 \mathrm{~cm}$ layer in the municipality of Lagoa Seca-PB.

\section{Soil analysis}

After collection, the composite soil sample was air-dried, passed through a 2-mm-mesh sieve and characterized according to Teixeira et al. (2017) for the following physical attributes: clay $=158.5 \mathrm{~g} \mathrm{~kg}^{-1}$, silt $=120.7 \mathrm{~g} \mathrm{~kg}^{-1}$ and sand $=$ $720.8 \mathrm{~g} \mathrm{~kg}^{-1}$, and chemical attributes: $\mathrm{pH}=5.75$; $\mathrm{EC}=0.16 \mathrm{dS}$ $\mathrm{m}^{-1} ; \mathrm{Ca}=1.56 \mathrm{cmol}_{\mathrm{c}} \mathrm{kg}^{-1} ; \mathrm{Mg}=1.18 \mathrm{cmol}_{\mathrm{c}} \mathrm{kg}^{-1} ; \mathrm{Na}=0.06$ $\mathrm{cmol}_{\mathrm{c}} \mathrm{kg}^{-1} ; \mathrm{K}=0.26 \mathrm{cmol}_{\mathrm{c}} \mathrm{kg}^{-1} ; \mathrm{H}=1.27 \mathrm{cmol}_{\mathrm{c}} \mathrm{kg}^{-1} ; \mathrm{P}=4.9 \mathrm{mg}$ $\mathrm{kg}^{-1} ; \mathrm{OM}=14.8 \mathrm{~g} \mathrm{~kg}^{-1}$.

\section{Biochar analysis}

The biochar used in the experiment was produced using poultry litter and had the following composition: $\mathrm{N}=3.45 \%$; $\mathrm{P}_{2} \mathrm{O}_{5}=7.78 \% ; \mathrm{K}_{2} \mathrm{O}=4.90 \%$; Calcium $=6.83 \%$; Magnesium $=$ $1.34 \%$; Sulfur $=0.76 \%$; Iron $=0.46 \%$; Manganese $=0.09 \%$; Copper $=0.04 \%$; Zinc $=0.08 \%$; Boron $=0.01 \%$; $\mathrm{pH}=9.45$; Carbon/nitrogen ratio $=11.53 \%$; Organic carbon $=39.77 \%$; Organic matter $=68.56 \%$ and $C E C=388.90 \mathrm{mmol}_{\mathrm{c}} / \mathrm{kg}$.

\section{Design and treatments}

The experimental design was completely randomized in a $4 \mathrm{x}$ 4 factorial scheme, composed of four doses of nitrogen (N) $\left(0 ; 40 ; 80\right.$ and $\left.120 \mathrm{~kg} \mathrm{ha}^{-1}\right)$ and four doses of biochar $(0 ; 7 ; 14$ and $21 \mathrm{~m}^{3} \mathrm{ha}^{-1}$ ), with three replicates, totaling 48 experimental units. These doses were defined based on the recommendations of $\mathrm{N}$ fertilization and organic matter (bovine manure, $20 \mathrm{~m}^{3} \mathrm{ha}^{-1}$ ) for the bell pepper crop (Cavalcanti, 1998).

\section{Experimental setup and conduction of study}

Each experimental unit consisted of one $8-\mathrm{dm}^{3}$ polyethylene pot (Citropote), covered at the bottom with geotextile (Bidim OP 30), and filled with $0.3 \mathrm{~kg}$ of crushed stone ( $\mathrm{n}-0$ ) and $6.0 \mathrm{~kg}$ of soil material. After filling, biochar was incorporated in each experimental unit in the upper part of the soil material and the mixture was irrigated until reaching moisture content corresponding to $80 \%$ field capacity, for the experimental units to remain incubated for 8 days. Bell pepper seedlings (All Big cultivar, belonging to the Cascadura group) were prepared on a plastic tray, using a commercial substrate, where 3 seeds were planted in each tray cell; at 28 days after sowing (DAS), the seedlings were transplanted to the pots and thinning was carried out 8 days after transplanting, leaving only one plant per pot. Plants were daily irrigated with the water volumes required to reach $80 \%$ soil field capacity. Bell pepper plants were staked until the end of the cycle to assist in their support.

After thinning, the experimental units were fertilized with $120 \mathrm{~kg} \mathrm{ha}{ }^{-1}$ of phosphorus (46 mg/pot), $70 \mathrm{~kg} \mathrm{ha}^{-1}$ of potassium (26.8 $\mathrm{mg} /$ pot), 40, 80 and $120 \mathrm{~kg} \mathrm{ha}^{-1}$ of nitrogen (16.7; 33.3 and $50 \mathrm{mg} /$ pot, respectively), using monoammonium phosphate, potassium chloride and urea as sources. In order to meet the requirements of micronutrients, plants were sprayed at 30, 45 and 60 DAS, with a solution $\left(2.5 \mathrm{~g} \mathrm{~L}^{-1}\right)$ with the following composition: $\mathrm{N}$ (15\%); $\mathrm{P}_{2} \mathrm{O}_{5}(15 \%) ; \mathrm{K}_{2} \mathrm{O}(15 \%) ; \mathrm{Ca}(1 \%) ; \mathrm{Mg}(1.4 \%) ; \mathrm{S}(2.7 \%)$; Zn (0.5\%); B (0.05\%); Fe (0.5\%); Mn (0.05\%); Cu (0.5\%); Mo (0.02\%).

\section{Variables analyzed}

Ripe fruits were harvested at weekly intervals from 80 DAS to evaluate the number of fruits (NF) and fruit fresh weight (FFW). In order to obtain the dry weight (FDW), fruits were placed in paper bags and dried in forced air circulation oven at temperature of 65 oc until constant weight. Fruit longitudinal (FLD) and transverse (FTD) diameters were measured with a digital caliper.

Photosynthetic pigments (chlorophyll $a$, chlorophyll $b$ and carotenoids) were quantified by following the laboratory method developed by Arnon (1949), preparing plant extracts from samples of discs of the lamina of the third mature leaf from the apex. These extracts were used to determine the contents of chlorophyll and carotenoids in the solution using a spectrophotometer at the absorbance wavelength (ABS) (470, 646, and $663 \mathrm{~nm})$, according to the following equations:

Chlorophyll $a($ Chla $)=(12.21 \times$ ABS663 $)-(2.81 \times$ ABS646 $)$

Chlorophyll $b$ (Chlb) $=(20.13 \times$ ABS64 $)-(5.03 \times$ ABS663 $)$

Carotenoids $($ Car $)=((1000 \times$ ABS470 $)-(1.82 \times$ Chla $)-(85.02$ $x$ Chlb))/198.

The obtained contents of chlorophyll $a$, chlorophyll $b$ and carotenoids in the leaves were expressed in $\mu \mathrm{m} \mathrm{g}^{-1} \mathrm{FM}$ (fresh matter).

\section{Statistical analysis}

The collected data were subjected to analysis of variance by $\mathrm{F}$ test at 0.05 and 0.01 probability levels. When significant, linear and quadratic polynomial regression analysis was carried out using the statistical program SISVAR (Ferreira, 2014).

\section{Conclusions}

Fertilization with $70 \mathrm{~kg} \mathrm{ha}^{-1}$ of nitrogen associated with 14 $\mathrm{m}^{3} \mathrm{ha}^{-1}$ of biochar promoted the highest yield of bell pepper in terms of number of fruits and fruit fresh weight per plant. The highest contents of photosynthetic pigments were obtained in plants fertilized with $70 \mathrm{~kg} \mathrm{ha}^{-1}$ of nitrogen associated with $10 \mathrm{~m}^{3} \mathrm{ha}^{-1}$ of biochar.

Biochar doses above $15.54 \mathrm{~m}^{3} \mathrm{ha}^{-1}$ negatively affect the longitudinal diameter of bell pepper fruits. 
The recommendation of $120 \mathrm{~kg} \mathrm{ha}^{-1}$ of nitrogen and $20 \mathrm{~m}^{3}$ $\mathrm{ha}^{-1}$ of biochar reduces bell pepper production and photosynthetic pigments.

\section{References}

Arnon DI (1949) Copper enzymes in isolated cloroplasts: polyphenoloxidases in Beta vulgaris. Plant Physiol. 24:115.

Ayodele OJ, Alabi EO, Aluko M (2015) Nitrogen fertilizer effects on growth, yield and chemical composition of hot pepper (Rodo). Int J Agric Crop Sci. 8:666-673.

Aragão VF, Fernandes PD, Gomes Filho RR, Carvalho CM, Oliveira HF, Oliveira EF (2013) Produção e eficiência no uso de água do pimentão submetido a diferentes lâminas de irrigação e níveis de nitrogênio. Rev Bras Agric Irrig. 6:207216.

Bhuvaneswari G, Sivaranjani R, Reetha S, Ramakrishan K (2014) Application of nitrogen fertilizer on plant density, growth, yield and fruit of bell peppers (Capsicum annuum L.). Int Let Nat Sci. 8: 81-90.

Campos VB, Oliveira A, Cavalcante LF, Prazeres S (2008) Rendimento do pimentão submetido ao nitrogênio aplicado via água de irrigação em ambiente protegido. Rev Bio Ci Ter. 8:72-79.

Cavalcanti FJA (1998) Recomendação de adubação para o estado de Pernambuco ( $2^{\circ}$ aproximação). IPA, Pernambuco.

Chaves LHG, Lima WB, Chaves IB, Silva BJ, Fook MVL, Lima SJW (2018) Effect of poultry litter biochar on Ultisol physical properties. Afr J Agric Res. 13:412-418.

Chen $Y X$, Huang $X D$, Han $Z Y$, Huang $X$, Hu B, Shi DZ, Wu WX (2010) Effects of bamboo charcoal and bamboo vinegar on nitrogen conservation and heavy metals immobility during pig manure composting. Chemosphere 78:1177-1181.

Coelho MA, Fusconi R, Pinheiro L, Ramos IC, Ferreira AS (2018) The combination of compost or biochar with urea and NBPT can improve nitrogen-use efficiency in maize. Anais da Acad Bras Cie. 90:1695-1703.

FAO. Faostat - Statistics Database. Disponivel em: http://www.fao.org/statistics/en/

Acessado em: 17 de Janeiro de 2019.

Ferreira MMM, Ferreira GB, Fontes PCR, Dantas JP (2003) Produção do tomateiro em função de doses de nitrogênio e da adubação orgânica em duas épocas de cultivo. Hort Bras. 21:468-473.

Ferreira DF (2014) Sisvar: A guide for its bootstrap procedures in multiple comparisons. Cie Agrot. 38:109112.

Godlewska P, Schmidt HP, Ok YS, Oleszczuk P (2017) Biochar for composting improvement and contaminants reduction. A review. Bior Tech. 246:193-202.

Gwenzi W, Muzava M, Mapanda F, Tauro TP (2016) Comparative short-term effects of sewage sludge and its biochar on soil properties, maize growth and uptake of nutrients on a tropical clay soil in Zimbabwe. J Integ Agric. 15:1395-1406.
Hammer EC, Balogh-Brunstad Z, Jakobsen I, Olsson PA, Stipp SL, Rillig MC (2014) A mycorrhizal fungus grows on biochar and captures phosphorus from its surfaces. Soil Bio \& Bioch. 77: 252-260.

Kavitha B, Reddy PVL, Kim B, Lee SS, Pandey SK, Kim KH (2018) Benefits and limitations of biochar amendment in agricultural soils: A review. J Envir Manag. 227:146-154.

Lima GS, Santos JB, Soares LAA, Gheyi HR, Nobre RG, Pereira RF (2016) Irrigação com águas salinas e aplicação de prolina foliar em cultivo de pimentão 'All Big'. Com Sci 7:513-522.

Liu Z, Chen X, Jing Y, Li Q, Zhang J, Huang Q (2014) Effects of biochar alteration on rape and sweet potato production and stable aggregation in water on red dry soil. Catena 123: 45-51.

López-Cano I, Roig A, Cayuela ML, Alburquerque JA, SánchezMonedero MA (2016) Biochar improves N cycling during composting of olive mill wastes and sheep manure. Waste Manag. 49: 553-559.

Nascimento WM (2014) Produção de sementes de hortaliças. Embrapa Hortaliças, Brasília.

Silva MDA, Santos CMD, Vitorino HDS, Lima Rhein AFD (2014) Pigmentos fotossintéticos e índice Spad como descritores de intensidade do estresse por deficiência hídrica em cana-de-açúcar. Biosci J. 30:173-181.

Silva ICB, Fernandes LA, Colen F, Sampaio RA (2017) Growth and production of common bean fertilized with biochar. Cienc Rural. 47:1-8.

Souza RJ, Nannetti DC (1998) A cultura do pimentão (Capsicum annuum L.). UFLA, Lavras (Boletim técnico).

Souza IL, Tomazella VB, Santos AJN, Moraes T, Silveira LCP (2018) Parasitoids diversity in organic Sweet Pepper (Capsicum annuum) associated with Basil (Ocimum basilicum) and Marigold (Tagetes erecta). Braz J Bio. 1:1-9.

Streit NM, Canterle LP, Canto MW, Hecktheuer LHH (2005) As clorofilas. Ci R. 35:748-755.

Tammeorg P, Bastos AC, Jeffery S, Rees F, Kern J, Graber ER, Cordovil CMDS (2017) Biochars in soils: towards the required level of scientific understanding. J Env Eng Lands Manag. 25:192-207.

Taiz L, Zeiger E (2017) Fisiologia vegetal. 6 ed. Artmed, Porto Alegre.

Teixeira PC, Donagemma GK, Fontana A, Teixeira WG (2017) Manual de métodos de análise de solo, 3.ed. Brasília: Embrapa Solos.

Vanotti MB, Bundy LG (1994) An alternative rationale for corn nitrogen fertilizer recommendations. J Prod Agric. 7:243-249.

Zhao J, Ni T, Li J, Lu Q, Fang Z, Huang Q, Zhang R, Li R, Shen $B$, Shen $Q$ (2016) Effects of organic-inorganic compound fertilizer with reduced chemical fertilizer application on crop yields, soil biological activity and bacterial community structure in a rice-wheat cropping system. Appl Soil Ecol. 99:1-12. 